\title{
Differential Roles of Hydrogen Peroxide and Superoxide in Mediating IL-1-Induced NF-KB Activation and iNOS Expression in Bovine Articular Chondrocytes
}

\author{
Alexandrina Ferreira Mendes, ${ }^{1,2 *}$ M. Margarida Caramona, ${ }^{1}$ A. Pato Carvalho, ${ }^{2}$ and M. Celeste Lopes ${ }^{1,2}$ \\ ${ }^{1}$ Faculty of Pharmacy, University of Coimbra, Rua do Norte, 3000-295 Coimbra, Portugal \\ ${ }^{2}$ Centre for Neurosciences of Coimbra, Department of Zoology, University of Coimbra, \\ 3004-517 Coimbra, Portugal
}

\begin{abstract}
Our previous studies showed that reactive oxygen species (ROS) are required for the pro-inflammatory cytokine interleukin-1 $\beta$ (IL-1) to induce the activity of the Nuclear transcription Factor-kappaB (NF- $\kappa \mathrm{B}$ ) and the expression of the inducible isoform of the nitric oxide synthase (iNOS) in bovine articular chondrocytes. This study aimed at elucidating the role of hydrogen peroxide $\left(\mathrm{H}_{2} \mathrm{O}_{2}\right)$ and the superoxide radical, two major ROS, in mediating those IL-1induced responses. The results obtained show that chondrocytes produce both $\mathrm{H}_{2} \mathrm{O}_{2}$ and superoxide radical in response to IL-1. Treatment of the chondrocyte cultures with $\mathrm{H}_{2} \mathrm{O}_{2}$ alone did not induce NF- $\mathrm{KB}$ activation or iNOS expression. Addition of $\mathrm{H}_{2} \mathrm{O}_{2}$ simultaneously with IL-1 did neither enhance nor inhibit NF- $\mathrm{\kappa B}$ activation and iNOS expression, relatively to treatment with IL-1 alone. Accordingly, treatment with catalase did not inhibit those IL-1-induced responses. Treatment with superoxide dismutase, however, effectively prevented IL-1-induced I $\mathrm{KB}-\alpha$ degradation and iNOS expression. Taken together, the results obtained indicate that superoxide mediates IL-1-induced I $\kappa \mathrm{B}-\alpha$ degradation and the consequent NF- $\kappa$ B activation and iNOS expression in chondrocytes, whereas $\mathrm{H}_{2} \mathrm{O}_{2}$ does not seem to participate in those IL-1-induced responses. In conclusion, the present study identifies the superoxide radical as the ROS involved in mediating the IL-1-induced signaling pathway that leads to NF- $\mathrm{BB}$ activation and to the expression of NF- $\mathrm{BB}-\mathrm{dependent}$ genes in bovine articular chondrocytes. J. Cell. Biochem. 88: 783-793, 2003. ( 2003 Wiley-Liss, Inc.
\end{abstract}

Key words: hydrogen peroxide; superoxide radical; interleukin-1 $\beta$; NF-кB; iNOS expression; chondrocyte

Interleukin-1 $\beta$ (IL-1), a potent pro-inflammatory cytokine, was shown to induce a series of catabolic responses in chondrocytes that lead to cartilage degradation and inflammation, the major pathogenic events common to all arthritic processes [Pelletier et al., 1993; Weyand, 2000].

The transcription factor, Nuclear Factor kappaB (NF- $\mathrm{BB})$, seems to play a major role in mediating IL-1-induced cellular responses. $\mathrm{NF}-\mathrm{\kappa B}$ regulates the expression of many inflam-

Grant sponsor: Portuguese Foundation for Science and Technology (FCT).

*Correspondence to: Alexandrina Ferreira Mendes, Centre for Neurosciences of Coimbra, Department of Zoology, University of Coimbra, 3004-517 Coimbra, Portugal.

E-mail: alexandrinam@hotmail.com

Received 27 May 2002; Accepted 30 August 2002

DOI 10.1002/jcb.10428

(c) 2003 Wiley-Liss, Inc. mation-related genes, including cyclooxygenase-2 (COX-2) [Lukiw and Bazan, 1998], inflammatory cytokines [Siebenlist et al., 1994; Yoshida et al., 1999], adhesion molecules [Iademarco et al., 1992; Kaszubska et al., 1993], and the inducible isoform of nitric oxide (NO) synthase (iNOS), which produces large amounts of NO [Xie et al., 1994; Eberhardt et al., 1998]. IL-1 has been shown to activate NF- $\mathrm{KB}$ by inducing the phosphorylation and degradation of I $\mathrm{KB}-\alpha$, a member of the Inhibitor $\kappa \mathrm{B}$ (I $\kappa \mathrm{B})$ family of proteins, which allows the translocation to the nucleus of the active NF- $\mathrm{KB}$ dimers [Beg et al., 1993]. Recently, we observed that IL1 activates NF- $\mathrm{KB}$ in chondrocytes, which is an essential requirement for the expression of iNOS and for the subsequent production of $\mathrm{NO}$ [Mendes et al., 2001, 2002a,b,c].

Despite extensive investigation of the responses and signaling pathways utilized by IL-1 in different cells, the mechanisms that link IL-1-binding to its receptor to the activation of 
transcription factors and subsequent gene expression are still incompletely understood. In recent years, reactive oxygen species (ROS) and reactive nitrogen species, namely NO, have been increasingly recognized as signaling intermediates of IL-1-induced responses in many cell types [Blanco and Lotz, 1995; Sen, 1998; Eberhardt et al., 2002]. Changes in the redox state of the cells, resulting from alterations in the rate of ROS generation and/or in the intracellular levels of antioxidants, have been associated with modifications in the pattern of gene expression, which in turn result from changes in the activity of many transcription factors [Allen and Tresini, 2000; Schoonbroodt and Piette, 2000].

Accumulating evidence indicates that NF- $\mathrm{KB}$ is sensitive to redox regulation. Nevertheless, the role of ROS on NF- $\kappa \mathrm{B}$ activation seems to be highly dependent on the cell-type, since the same stimulus, hydrogen peroxide $\left(\mathrm{H}_{2} \mathrm{O}_{2}\right)$ for instance, can have opposite effects on the activity of this transcription factor when acting in different cells [Meyer et al., 1993; Wesselborg et al., 1997; Flescher et al., 1998; Lakshminarayanan et al., 1998; Woods et al., 1999].

IL-1 has been shown to induce chondrocytes to produce several types of ROS, including $\mathrm{H}_{2} \mathrm{O}_{2}$ [Rathakrishnan et al., 1992] and hydroxyl [Tiku et al., 1998] and superoxide [Tawara et al., 1991] radicals. Furthermore, ROS have been shown to be required for IL-1-induced NF- $\mathrm{KB}$ activation and iNOS expression [Mendes et al., 2001], as well as for the expression of c-Fos and collagenase [Lo et al., 1998]. ROS, and $\mathrm{H}_{2} \mathrm{O}_{2}$ in particular, have also been shown to mediate IL1-induced expression of c-Jun in articular chondrocytes [Lo et al., 1996]. Moreover, chondrocyte-derived ROS have also been reported to mediate cartilage matrix destruction by inducing aggrecan and collagen degradation [Tiku et al., 1999, 2000].

Nevertheless, it is not clear whether ROS, in general, mediate those IL-1-induced responses, or, instead, a specific type of ROS is responsible for mediating activation of a particular signaling pathway leading to a specific response. Since, under appropriate conditions, $\mathrm{H}_{2} \mathrm{O}_{2}$ and the superoxide radical can generate other types of ROS, this study first attempted to identify the ability of chondrocytes to produce those two types of ROS in response to IL-1. Then, this study aimed at elucidating the role of $\mathrm{H}_{2} \mathrm{O}_{2}$ and superoxide in mediating IL-1-induced NF- $\mathrm{KB}$ activation and iNOS expression in bovine articular chondrocytes.

\section{MATERIALS AND METHODS}

\section{Materials}

Recombinant human IL-1 $\beta$ was purchased from R\&D Systems (Abingdon, UK). Catalase, superoxide dismutase (SOD), and $\mathrm{H}_{2} \mathrm{O}_{2}$ were from Sigma Chemical Co. (St. Louis, MO). The anti-iNOS antibody was from Transduction Laboratories (Lexington, KY). The anti-IкB- $\alpha$ antibody was from New England Biolabs, Inc. (Beverly, MA). The anti-actin antibody was from Boehringer Mannheim (Mannheim, Germany). The oligonucleotide probe containing the consensus binding site for NF- $\mathrm{KB}$ was from Santa Cruz Biotechnology, Inc. (Santa Cruz, CA). The protease inhibitors cocktail, "Complete, Mini" was from Roche Molecular Biochemicals (Mannheim, Germany). The isotopes were from Amersham Pharmacia Biotech, Inc. (Piscataway, NJ). The c-DNA probes for iNOS and glyceraldehyde-3-phosphate dehydrogenase (GAPDH) were a kind gift from Dr. Tony Cruz (Samuel Lunenfeld Research Institute, Mount Sinai Hospital, Toronto, Canada).

\section{Isolation and Cell Culture}

Chondrocytes were isolated from bovine articular cartilage, as described previously [Cruz et al., 1990]. Primary confluent monolayer cultures were set up by plating $2 \times 10^{6}$ cells $/ \mathrm{ml}$ in Ham's F-12 medium containing $3 \%$ antibiotic/antimycotic solution and $5 \%$ fetal bovine serum and allowed to recover for $24 \mathrm{~h}$ at $37^{\circ} \mathrm{C}$ in a humidified atmosphere supplemented with $5 \% \mathrm{CO}_{2}$. Prior to any treatments, the cells were serum-starved overnight and, thereafter, maintained in culture medium with $1 \%$ antibiotic/ antimycotic solution and without serum. In all the experiments using catalase and SOD, the cells, including those left untreated and those treated with IL-1 alone, were permeabilized by addition of digitonin $0.00002 \%$ prior to any other treatment.

\section{Measurement of ROS Production}

The intracellular production of ROS was measured using $2^{\prime}, 7^{\prime}$-dichlorodihydrofluorescein diacetate $\left(\mathrm{DCFH}_{2}-\mathrm{DA}\right)$ as described previously [Bass et al., 1983; LeBel et al., 1990] with modifications. $\mathrm{DCFH}_{2}$-DA is a non-fluor- 
escent probe that, upon diffusion into the cells, is hydrolyzed by intracellular esterases to $2^{\prime}, 7^{\prime}$ dichlorodihydrofluorescein $\left(\mathrm{DCFH}_{2}\right)$, which is trapped within the cells. In the presence of ROS, particularly peroxides, $\mathrm{DCFH}_{2}$ is oxidized to the highly fluorescent compound $2^{\prime}, 7^{\prime}$-dichlorofluorescein (DCF).

Chondrocytes $\left(2 \times 10^{6}\right)$ were loaded with $5 \mu \mathrm{M}$ $\mathrm{DCFH}_{2}$-DA in $\mathrm{Na}^{+}$saline solution $(140 \mathrm{mM}$ $\mathrm{NaCl}, 5 \mathrm{mM} \mathrm{KCl}, 1.5 \mathrm{mM} \mathrm{CaCl}_{2}, 1.0 \mathrm{mM} \mathrm{MgCl}_{2}$, $1.0 \mathrm{mM} \mathrm{NaH}{ }_{2} \mathrm{PO}_{4}, 5.6 \mathrm{mM}$ glucose, $20.0 \mathrm{mM}$ Hepes, $\mathrm{pH}$ 7.4) for $20 \mathrm{~min}$, at $37^{\circ} \mathrm{C}$. After rinsing, the cells were incubated for $30 \mathrm{~min}$ with $80 \mathrm{U} / \mathrm{ml}$ of catalase or SOD in $\mathrm{Na}^{+}$saline solution with $0.00002 \%$ digitonin. Then, IL-1 $(5 \mathrm{ng} / \mathrm{ml})$ was added to the corresponding wells and the cells further incubated for another $30 \mathrm{~min}$. The fluorescence intensity of the cells was measured immediately at $37^{\circ} \mathrm{C}$, using a SPEX Fluorolog spectrometer, equipped with a thermostated waterbath, with excitation set at $502 \mathrm{~nm}$ and emission set at $550 \mathrm{~nm}$.

\section{Preparation of Cytoplasmic and Nuclear Extracts}

The cells were lysed in $400 \mu \mathrm{l}$ of buffer 1 (10 mM Tris- $\mathrm{HCl}, 10 \mathrm{mM} \mathrm{NaCl}, 3 \mathrm{mM} \mathrm{\textrm {MCl } _ { 2 }}$, $0.5 \%$ Nonidet $\mathrm{P}-40$, protease inhibitors cocktail at 1:7 dilution, $\mathrm{pH}$ 7.5) and incubated on ice for $15 \mathrm{~min}$. The lysates were centrifuged at $2,300 \mathrm{~g} /$ $5 \mathrm{~min} / 4^{\circ} \mathrm{C}$ and the supernatants (cytoplasmic extracts) were collected and stored at $-70^{\circ} \mathrm{C}$. The pellets were resuspended in $30 \mu \mathrm{l}$ of buffer 2 (20 mM HEPES, $5 \mathrm{mM} \mathrm{MgCl}_{2}, 0.2 \mathrm{mM}$ EDTA, $1 \mathrm{mM}$ DTT, $300 \mathrm{mM} \mathrm{NaCl}, 20 \%$ Glycerol, protease inhibitors cocktail at 1:7 dilution, $\mathrm{pH}$ 7.5). After a $20 \mathrm{~min}$ incubation on ice, the pellet lysates were centrifuged at $18,000 \mathrm{~g} /$ $20 \mathrm{~min} / 4^{\circ} \mathrm{C}$ and the supernatants (nuclear extracts) were collected and stored at $-70^{\circ} \mathrm{C}$. The protein concentration of the extracts was measured using the bicinchoninic acid/copper (II) sulfate protein assay kit (Sigma Chemical Co., St. Louis, MO).

\section{Western Blot Analysis}

The cytoplasmic extracts ( $25 \mu \mathrm{g}$ protein) were diluted in sodium dodecylsulfate (SDS) sample buffer (2.5\% SDS, $0.0625 \mathrm{M}$ Tris-HCl, $10 \%$ glycerol, 5\% 2-mercaptoethanol, $0.05 \%$ bromophenol blue, $\mathrm{pH}$ 6.8) and boiled for $3 \mathrm{~min}$ at $90^{\circ} \mathrm{C}$. Proteins were separated by SDS/PAGE $[10 \%(\mathrm{w} / \mathrm{v})$ gel] and transferred onto polyvinylidene difluoride (PVDF) membranes by elec- troblotting. The membranes were blocked with $5 \%$ skim milk in Tris-buffered saline-Tween (TBS-T, 20mM Tris-HCl, $150 \mathrm{mM} \mathrm{NaCl}, 0.1 \%$ Tween-20) and then probed with the anti-iNOS or anti-IкB- $\alpha$ antibodies. After extensive washing with TBS-T, the blots were incubated with a horseradish peroxidase-conjugated anti-rabbit antibody (Dako A/S, Copenhagen, Denmark). The protein-antibody complexes were visualized by chemiluminescence using the ECL Western blotting detection reagents from Amersham Pharmacia Biotech, Inc. (Piscataway, NJ). The membranes were subsequently stripped and reprobed with an anti-actin antibody to ensure an equal protein loading.

\section{Electrophoretic Mobility Shift Assay (EMSA)}

The NF- $\kappa \mathrm{B}$ oligonucleotide probe was endlabeled with $\left[\gamma_{-}{ }^{32} \mathrm{P}\right]$ ATP by the T4 polynucleotide kinase and purified through Sephadex G-50 spin columns. Nuclear extracts $(10 \mu \mathrm{g}$ protein) were incubated for $40 \mathrm{~min}$ at $4^{\circ} \mathrm{C}$ in $20 \mu \mathrm{l}$ binding reactions containing $20 \mathrm{mM}$ HEPES, $50 \mathrm{mM}$ $\mathrm{KCl}, 1 \mathrm{mM} \mathrm{MgCl}_{2}, 0.5 \mathrm{mM}$ DTT, $4 \%$ Ficoll 400, $2 \mu \mathrm{g}$ poly(dIdC), $20 \mu \mathrm{g} \mathrm{BSA}, \mathrm{pH} 7.9$, and $200,000 \mathrm{cpm} /$ reaction of $\left[\gamma_{-}{ }^{32} \mathrm{P}\right]$-labeled oligonucleotide probe. The DNA-protein complexes were resolved by electrophoresis on $7 \%$ native polyacrylamide gels in $0.5 \times \mathrm{TBE}$ for $3 \mathrm{~h}$ at $150 \mathrm{~V}$, dried and visualized by autoradiography.

\section{Northern Blot Analysis}

Total RNA was extracted using Trizol (Gibco BRL, Life Technologies Inc., Grand Island, NY) and quantitated by spectrophotometry at $260 \mathrm{~nm}$. Denatured RNA samples $(20 \mu \mathrm{g})$ were analyzed by gel electrophoresis in a $1 \%$ denaturing agarose gel, transferred to a nylon membrane, and cross-linked by heating at $80^{\circ} \mathrm{C}$ for $30 \mathrm{~min}$. The blots were hybridized with a ${ }^{32}$ P-labeled iNOS c-DNA probe, subsequently stripped and reprobed with a ${ }^{32} \mathrm{P}$-labeled glyceraldehyde-3-phosphate dehydrogenase (GAPDH) c-DNA as an internal standard to insure a roughly equal loading. The c-DNA probes were labeled with $\left[\alpha-{ }^{32} \mathrm{P}\right] \mathrm{dCTP}$ by the klenow fragment using the Random Primed DNA Labeling kit from Boehringer Mannheim GmbH (Mannheim, Germany).

\section{Measurement of NO Production}

NO production was measured as the amount of nitrite released into the culture supernatant. Nitrite concentration was determined in 
cell-free culture supernatants using the spectrophotometric method based on the Griess reaction [Green et al., 1982].

\section{RESULTS}

\section{ROS Produced in Response to IL-1 Include $\mathrm{H}_{2} \mathrm{O}_{2}$ and Superoxide}

To measure the intracellular ROS production, we used $\mathrm{DCFH}_{2}$, a probe that becomes fluorescent upon oxidation and that is particularly sensitive to peroxides, although it can also react with the superoxide radical [Bass et al., 1983; LeBel et al., 1990]. We have previously observed that chondrocytes produce ROS in response to IL-1 [Mendes et al., 2001]. To identify the ROS produced in response to IL-1, we treated the chondrocyte cultures, preloaded with $\mathrm{DCFH}_{2}$, with catalase or superoxide dismutase (SOD), in the presence of IL-1, as described under Materials and Methods. The results obtained (Table I) show that treatment with IL-1 for 30 min increased the fluorescence intensity of the chondrocytes by approximately $18 \%$ relatively to control cells. Pretreatment with catalase reverted the effect of IL-1, so that the fluorescence intensity did not increase above that obtained in control. This indicates that IL-1 induced the production of $\mathrm{H}_{2} \mathrm{O}_{2}$, which was hydrolyzed by catalase, thus preventing the oxidation of $\mathrm{DCFH}_{2}$. On the opposite, when the cells were treated with SOD, the fluorescence intensity was higher than that obtained in cells treated with IL-1 alone. This can be explained by the greater sensitivity of $\mathrm{DCFH}_{2}$ to oxidation by $\mathrm{H}_{2} \mathrm{O}_{2}$ than by superoxide, so that, in cells treated with $\mathrm{SOD}$, the superoxide radicals produced were converted to $\mathrm{H}_{2} \mathrm{O}_{2}$, thus increasing the amount of $\mathrm{DCFH}_{2}$ oxidized and so the fluorescence intensity of those cells. Taken together, these results indicate that, under the culture conditions used, chondrocytes produced both $\mathrm{H}_{2} \mathrm{O}_{2}$ and superoxide in response to IL-1.

\section{Superoxide, but not $\mathrm{H}_{2} \mathrm{O}_{2}$, Mediates IL-1-Induced NF-кB Activation}

To study the role of $\mathrm{H}_{2} \mathrm{O}_{2}$ on NF- $\kappa \mathrm{B}$ activation, we determined the levels of I $\mathrm{KB}-\alpha$ in the cytoplasmic extracts obtained from cells treated with $\mathrm{H}_{2} \mathrm{O}_{2}$ in the presence or absence of IL- 1 . We used the corresponding nuclear extracts to detect the presence of active $\mathrm{NF}-\kappa \mathrm{B}$ dimers by EMSA analysis with a $\left[\gamma_{-}{ }^{32} \mathrm{P}\right]$-labeled oligonucleotide probe containing the consensus binding sequence for $\mathrm{NF}-\kappa \mathrm{B}$.

The results in Figure 1A show that treatment of chondrocytes with IL-1 (5 ng/ml) for $30 \mathrm{~min}$

\section{TABLE I. Effect of Catalase and Superoxide Dismutase on Interleukin-1ß- (IL-1-) Induced Reactive Oxygen Species (ROS) Production}

\begin{tabular}{lcr}
\hline & Arbitrary units & \% Relatively to control \\
\hline Control & $2.059 \pm 0.027 \times 10^{7}$ & $100.0 \pm 1.3$ \\
IL-1, $5 \mathrm{ng} / \mathrm{ml}$ & $2.437 \pm 0.025 \times 10^{7 *}$ & $118.4 \pm 1.2$ \\
Catalase, $80 \mathrm{U} / \mathrm{ml}+\mathrm{IL}-1$ & $2.041 \pm 0.033 \times 10^{7 * *}$ & $99.2 \pm 1.6$ \\
$\mathrm{SOD}, 80 \mathrm{U} / \mathrm{ml}+\mathrm{IL}-1$ & $2.562 \pm 0.017 \times 10^{7 * * *}$ & $124.5 \pm 0.8$ \\
\hline The fluorescence intensity of chondrocyte cultures preloaded with $\mathrm{DCFH}_{2}-\mathrm{DA}$ was measured after \\
treatment with interleukin-1 $(\mathrm{IL}-1), 5$ ng/ml, in the presence or absence of the indicated concentration of \\
catalase or superoxide dismutase (SOD), as described in Materials and Methods. Results are expressed in \\
arbitrary units and as a percentage of the fluorescence intensity relatively to that obtained in control cells, \\
which were loaded with DCFH ${ }_{2}$-DA and permeabilized with 0.00002\% digitonin, but otherwise left \\
untreated. The results presented are the mean \pm SD of three independent experiments, each performed in \\
duplicate.
\end{tabular}

Fig. 1. Effect of $\mathrm{H}_{2} \mathrm{O}_{2}$ on nuclear transcription factor-kappaB

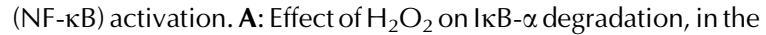
presence or absence of interleukin-1 $\beta$ (IL-1); (B) effect of $\mathrm{H}_{2} \mathrm{O}_{2}$ on NF-KB-DNA binding activity, in the presence or absence of IL-1. Chondrocyte cultures were treated with IL-1 $(5 \mathrm{ng} / \mathrm{ml})$ and/or the indicated concentrations of $\mathrm{H}_{2} \mathrm{O}_{2}$ for 30 min. The cytoplasmic extracts obtained from those cells were used to detect IкB- $\alpha$ protein levels by Western blot (panel A) and the corresponding nuclear extracts were used to detect NF- $\mathrm{\kappa B}$ binding to a specific oligonucleotide probe by EMSA (panel B), as described under Materials and Methods. The results shown are the mean \pm SD of the intensity, in arbitrary units, of the bands obtained, for each condition, in six different experiments using six distinct sets of cell cultures. ${ }^{*} P<0.01$ relatively to control cells; $\diamond P<0.01$ relatively to IL-1. Statistical significance was assessed by the unpaired Student's $t$-test. The autoradiographies shown are representative of six independent experiments. 

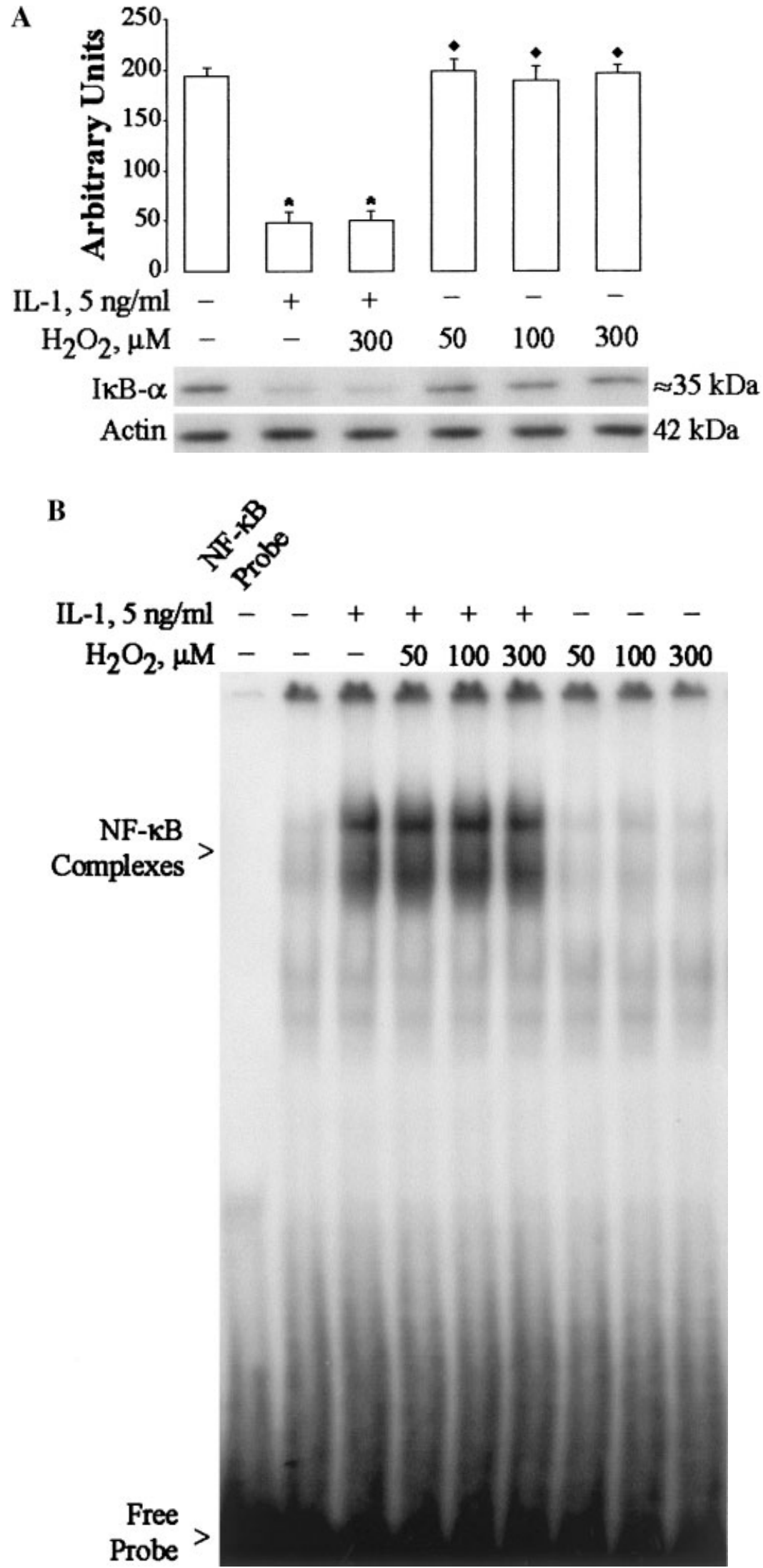

Fig. 1 
induced the degradation of $\mathrm{I}_{\kappa} \mathrm{B}-\alpha$, which was not altered by simultaneous incubation with $\mathrm{H}_{2} \mathrm{O}_{2}$ $(300 \mu \mathrm{M})$. On the other hand, the levels of IкB- $\alpha$ in the cytoplasmic extracts from cells treated for 30 min with $\mathrm{H}_{2} \mathrm{O}_{2}$ alone, in concentrations ranging from 50 to $300 \mu \mathrm{M}$, did not differ from those found in control cells, thus indicating that $\mathrm{H}_{2} \mathrm{O}_{2}$ alone does not induce $\mathrm{I} \kappa \mathrm{B}-\alpha$ degradation (Fig. 1A).

EMSA of nuclear extracts from IL-1-treated cells detected the binding of proteins to the $\left[\gamma_{-}{ }^{32} \mathrm{P}\right]$-labeled oligonucleotide probe containing the consensus sequence for NF-kB (Fig. 1B), thus reflecting NF- $\mathrm{NB}$ activation. When $\mathrm{H}_{2} \mathrm{O}_{2}$ $(50-300 \mu \mathrm{M})$ was added to the chondrocytes simultaneously with IL-1, no changes in the intensity of the NF- $\mathrm{KB}$-oligonucleotide probe complexes were detected relatively to those induced by IL-1 alone. In the absence of IL-1, nuclear extracts from chondrocyte cultures treated with $\mathrm{H}_{2} \mathrm{O}_{2}(50-300 \mu \mathrm{M})$ for $30 \mathrm{~min}$ did not show the formation of specific complexes between nuclear proteins and the NF- $\mathrm{KB}$ oligonucleotide probe, as compared with extracts from control cells (Fig. 1B). These results are in agreement with those obtained for the cytoplasmic levels of $\mathrm{I}_{\kappa} \mathrm{B}-\alpha$ and show that $\mathrm{H}_{2} \mathrm{O}_{2}$ alone is not sufficient to induce $\mathrm{NF}-\kappa \mathrm{B}$ activation in chondrocytes. Furthermore, these results also show that $\mathrm{H}_{2} \mathrm{O}_{2}$ does neither inhibit nor enhance IL-1-induced NF- $\kappa \mathrm{B}$ activation.

Nevertheless, these results do not exclude the possibility that $\mathrm{H}_{2} \mathrm{O}_{2}$ may be required, although not sufficient, for IL-1-induced NF- $\mathrm{BB}$ activation. To investigate this question, we treated the chondrocytes cultures with catalase or SOD in the presence of IL-1 and determined the cytoplasmic levels of IкB- $\alpha$. Figure 2 shows that pretreatment with SOD prevented IL1 -induced I $\mathrm{I} \mathrm{B}-\alpha$ degradation, whereas pretreatment with catalase had no effect on the cytoplasmic levels of IкB- $\alpha$.

Since treatment with catalase was effective in preventing IL-1-induced $\mathrm{DCFH}_{2}$ oxidation and the consequent increase in the fluorescence intensity, the lack of inhibition of $\mathrm{I} \kappa \mathrm{B}-\alpha$ degradation by catalase indicates that $\mathrm{H}_{2} \mathrm{O}_{2}$, although being produced, is not required for this IL-1-induced response. Furthermore, since neither $\mathrm{H}_{2} \mathrm{O}_{2}$ nor catalase had any effect on IкB$\alpha$ degradation, increased levels of $\mathrm{H}_{2} \mathrm{O}_{2}$ resulting from superoxide dismutation, cannot account for the inhibitory effect observed with SOD treatment. Instead the inhibitory effect observed with SOD treatment is more likely the result of decreased superoxide levels. Taken together, these results indicate that superoxide mediates IL-1-induced IкB- $\alpha$ degradation and

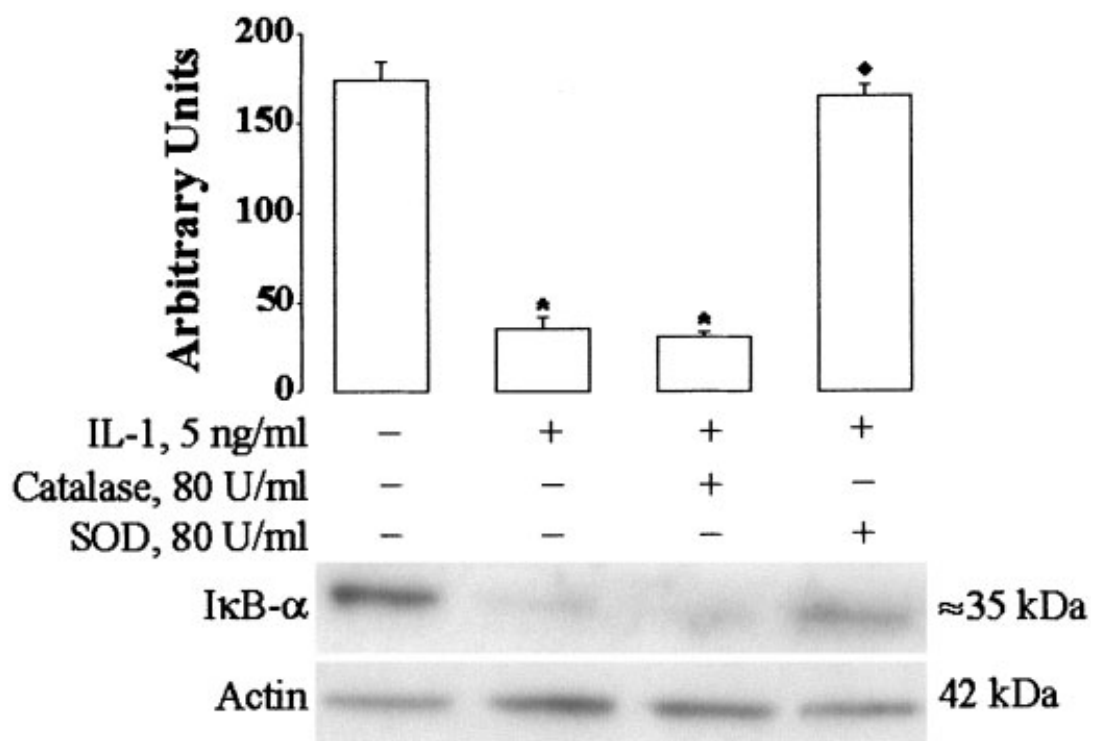

Fig. 2. Effect of catalase and superoxide dismutase (SOD) on interleukin-1 $\beta$ - (IL-1-) induced IкB- $\alpha$ degradation. Chondrocyte cultures were treated with catalase $(80 \mathrm{U} / \mathrm{ml})$ or SOD $(80 \mathrm{U} / \mathrm{ml})$ for $30 \mathrm{~min}$ before the addition of IL-1 $(5 \mathrm{ng} / \mathrm{ml})$ and then further incubated for another $30 \mathrm{~min}$. The cytoplasmic extracts obtained from those cells were used to detect IKB- $\alpha$ protein levels by Western blot, as described under Materials and Methods. The results shown are the mean \pm SD of the intensity, in arbitrary units, of the bands obtained, for each condition, in three different experiments using three distinct sets of cell cultures. ${ }^{*} P<0.01$ relatively to control cells; $P<0.01$ relatively to IL-1. Statistical significance was assessed by the unpaired Student's $t$-test. The autoradiography shown is representative of three independent experiments. 
the consequent NF- $\mathrm{\kappa B}$ activation in chondrocytes, whereas $\mathrm{H}_{2} \mathrm{O}_{2}$ does not seem to participate in this IL-1-induced response.

\section{Superoxide, but not $\mathrm{H}_{2} \mathrm{O}_{2}$, Is Required for IL-1-Induced iNOS Expression}

The results presented in Figure 3 show that $\mathrm{H}_{2} \mathrm{O}_{2}$ alone did not induce iNOS mRNA or protein synthesis, at any of the concentrations tested $(50-300 \mu \mathrm{M})$, and, when added simultaneously with IL-1 to the chondrocyte cultures, it did not alter the effect of the cytokine. Accordingly, treatment of the chondrocyte cultures with catalase, prior to the addition of IL-1 also had no effect on IL-1-induced iNOS mRNA (Fig. 4A) and protein (Fig. 4B) levels, as well as on its enzymatic activity (Fig. 4C) which was assessed as the amount of NO produced. In contrast, treatment with SOD decreased both the expression (Figs. 4A,B) and the enzymatic activity (Fig. 4C) of iNOS induced by IL-1. Therefore, superoxide, but not $\mathrm{H}_{2} \mathrm{O}_{2}$, seems to be required for the transcriptional induction of iNOS in response to IL-1, which is in agreement with the results obtained relatively to $\mathrm{NF}-\kappa \mathrm{B}$ activation.

\section{DISCUSSION}

In the present study, we first evaluated the ability of chondrocytes to produce $\mathrm{H}_{2} \mathrm{O}_{2}$ and superoxide radical in response to IL-1. The results obtained showed that chondrocytes produced both types of ROS in response to this cytokine (Table I), which is in agreement with previous studies [Tawara et al., 1991; Rathakrishnan et al., 1992].

In most cell types, treatment with $\mathrm{H}_{2} \mathrm{O}_{2}$ [Meyer et al., 1993; Wesselborg et al., 1997; Manna et al., 1998], or with enzymes that increase its intracellular level, such as superoxide dismutase [Schmidt et al., 1995], results in the activation of $\mathrm{NF}-\mathrm{\kappa B}$. Accordingly, treatment with antioxidants, such as $N$-acetylcysteine [Meyer et al., 1993] and pyrrolidine dithiocarbamate [Schreck et al., 1992], or with antioxidant enzymes, like catalase [Schmidt et al., 1995] and thioredoxin [Jin et al., 1997], effectively blocks induction by various stimuli. Since inhibition of IL-1-induced ROS production prevented NF- $\kappa B$ activation and the subsequent iNOS expression in chondrocytes [Mendes et al., 2001], here we investigated whether $\mathrm{H}_{2} \mathrm{O}_{2}$ could be the mediator of that response. However, the results show that $\mathrm{H}_{2} \mathrm{O}_{2}$, either alone or in combination with IL-1, had no effect on NF- $\mathrm{KB}$ activation (Fig. 1) and iNOS expression (Fig. 3) and that catalase was unable to block induction by IL-1 (Figs. 2 and 4). These results suggest that $\mathrm{H}_{2} \mathrm{O}_{2}$ is not required for $\mathrm{NF}-\kappa \mathrm{B}$ activation and iNOS expression in bovine articular chondrocytes.

A

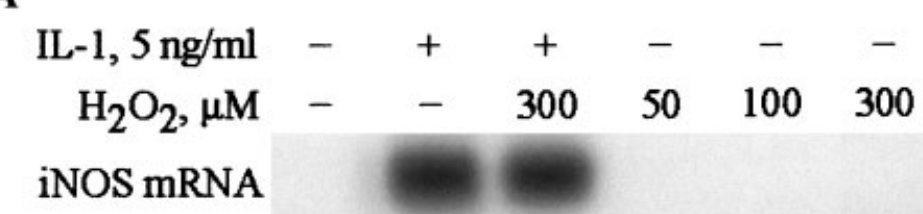

\section{GAPDH mRNA}

B

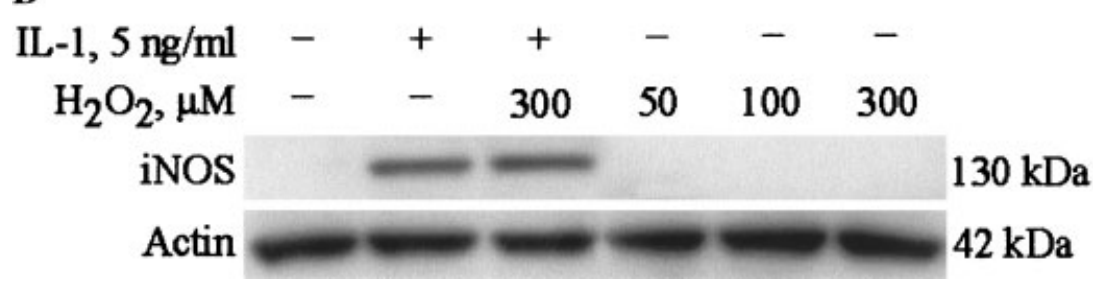

Fig. 3. Effect of $\mathrm{H}_{2} \mathrm{O}_{2}$ on the expression of the inducible isoform of the nitric oxide synthase (iNOS). A: Effect of $\mathrm{H}_{2} \mathrm{O}_{2}$ on iNOS mRNA levels, in the presence or absence of interleukin-1 $\beta$ (IL-1); (B) effect of $\mathrm{H}_{2} \mathrm{O}_{2}$ on iNOS protein levels, in the presence or absence of IL-1. Chondrocyte cultures were treated simultaneously with $\mathrm{H}_{2} \mathrm{O}_{2}(300 \mu \mathrm{M})$ and $\mathrm{IL}-1(5 \mathrm{ng} / \mathrm{ml})$, or with the indicated concentrations of $\mathrm{H}_{2} \mathrm{O}_{2}$ alone (from 50 to $300 \mu \mathrm{M}$ ), for
6 (panel A) or $16 \mathrm{~h}$ (panel B). Northern blot and Western blot analysis of iNOS mRNA and protein levels, respectively, were performed as described under Materials and Methods. The autoradiographies shown in panels $\mathrm{A}$ and $\mathrm{B}$ are representative of six independent experiments, which were performed using six distinct sets of cell cultures. 


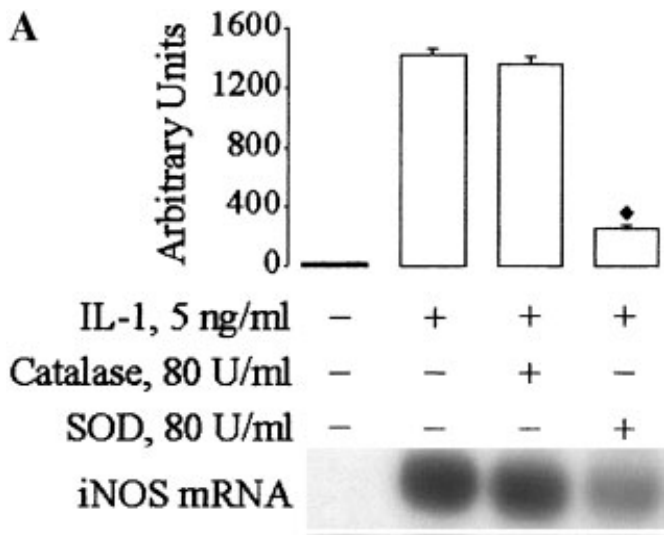

B



Fig. 4. Effect of catalase and superoxide dismutase (SOD) on interleukin-1 $\beta$ - (IL-1-) induced expression and activity of the inducible isoform of the nitric oxide synthase (iNOS). A: Effect of catalase and SOD on IL-1-induced iNOS mRNA levels; (B) effect of catalase and SOD on IL-1-induced iNOS protein levels. C: Effect of catalase and SOD on IL-1-induced iNOS activity, assessed as the amount of nitrite accumulated in the culture supernatants. Chondrocyte cultures were treated with catalase $(80 \mathrm{U} / \mathrm{ml})$ or SOD $(80 \mathrm{U} / \mathrm{ml})$ for $30 \mathrm{~min}$ before the addition of IL-1 $(5 \mathrm{ng} / \mathrm{ml})$ and then further incubated for 6 (panel A) or $16 \mathrm{~h}$ (panels $B$ and C). Northern blot and Western blot analysis of iNOS mRNA and protein levels, respectively, and measurement of nitrite

Interestingly, other studies also suggest that, in some cells, $\mathrm{H}_{2} \mathrm{O}_{2}$ does not have a prominent role on NF- $\mathrm{NB}$ activation and, in a few cases, $\mathrm{H}_{2} \mathrm{O}_{2}$ has been found to regulate this transcription factor negatively. In COS-1 cells, for instance, overexpression of catalase had no effect on NF- $\mathrm{KB}$ activation induced by TNF or phorbol esters [Suzuki et al., 1995], whereas, in stimulated T-lymphocytes, acute or chronic exposure to $\mathrm{H}_{2} \mathrm{O}_{2}$ blocked NF- $\mathrm{kB}$ activation [Flescher et al., 1998]. On the other hand, overexpression of manganese-SOD completely abolished TNF-
C
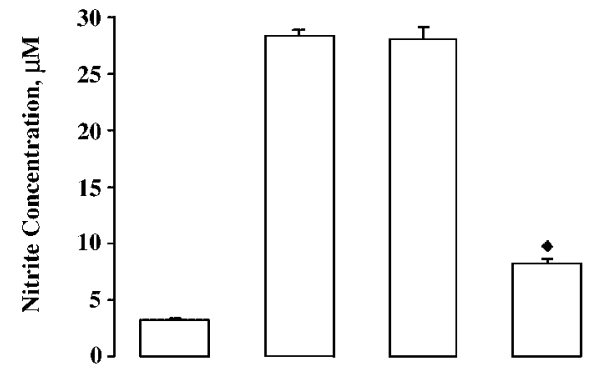

$130 \mathrm{kDa}$

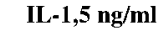

Catalase, $80 \mathrm{U} / \mathrm{ml}$

$\mathrm{SOD}, 80 \mathrm{U} / \mathrm{ml}$ concentration were performed as described under Materials and Methods. In panels $A$ and $B$, the results shown are the mean $\pm S D$ of the intensity, in arbitrary units, of the bands obtained, for each condition, in three different experiments which were performed using three distinct sets of cell cultures. The autoradiographies shown in panels $A$ and $B$ are representative of three independent experiments. In panel $C$, the results shown are the mean $\pm S D$ of the nitrite concentration determined in three independent experiments, each performed in triplicate. $\diamond P<0.01$ relatively to IL-1. Statistical significance was assessed by the unpaired Student's $t$-test.

induced NF- $\mathrm{KB}$ activation in a breast cancer cell line [Manna et al., 1998]. However, this study also reported that overexpression of SOD potentiated $\mathrm{H}_{2} \mathrm{O}_{2}$-induced $\mathrm{NF}-\mathrm{\kappa B}$ activation, rendering it difficult to ascertain which type of ROS was involved in NF-kB activation in those cells.

On the other hand, treatment with SOD prevented IL-1-induced IкB- $\alpha$ degradation (Fig. 2) and iNOS expression (Fig. 4). These inhibitory effects can only be accounted for by the action of this enzyme, that is, either by the reduced levels of superoxide radical or by the presence of 
increased amounts of $\mathrm{H}_{2} \mathrm{O}_{2}$. As to the last possibility, increased amounts of $\mathrm{H}_{2} \mathrm{O}_{2}$ could either inhibit or enhance the effects of IL-1. These possibilities were ruled out by the use of catalase and by the direct addition of $\mathrm{H}_{2} \mathrm{O}_{2}$ to chondrocyte cultures treated or not with IL-1. The absence of positive or negative effects in cells treated either with catalase and IL-1 (Figs. 2 and 4) or with $\mathrm{H}_{2} \mathrm{O}_{2}$, alone or in the presence of IL-1 (Figs. 1 and 3) shows that $\mathrm{H}_{2} \mathrm{O}_{2}$ is not only unable to induce $\mathrm{NF}-\kappa \mathrm{B}$ activation and iNOS expression in chondrocytes, but more importantly, that it does neither mediate nor inhibit those responses induced by IL-1. Moreover, Tiku et al. [1998] showed that the formation of the hydroxyl radical in chondrocytes requires the addition of exogenous iron and the presence of $\mathrm{H}_{2} \mathrm{O}_{2}$. Therefore, our results also exclude the hydroxyl radical, or any other ROS produced from $\mathrm{H}_{2} \mathrm{O}_{2}$, as being the mediator of IL-1-induced NF- $\mathrm{BB}$ activation and iNOS expression in chondrocytes. Hence, the inhibitory effects observed by treatment with SOD most probably result from the decreased availability of the superoxide radical. Taken together, the results presented indicate that the superoxide radical is the ROS involved in mediating IL-1-induced I $\kappa \mathrm{B}-\alpha$ degradation and the consequent NF- $\mathrm{KB}$ activation and iNOS expression in chondrocytes.

Our findings are in agreement with recent reports indicating that superoxide, rather than $\mathrm{H}_{2} \mathrm{O}_{2}$, is the ROS involved in mediating some IL-1-induced responses. Superoxide has been shown to act as a costimulatory factor amplifying matrix metalloproteinase- 9 expression in glomerular mesangial cells by enhancing IL-1induced activation of the mitogen-activated protein kinases, p38 and extracellular signalregulated kinase (ERK), and of the transcription factors NF- $\mathrm{KB}$ and activator protein-1 [Eberhardt et al., 2000]. In agreement with this report, IL-1-induced ERK activation and matrix metalloproteinase-9 expression, in vascular smooth muscle cells, were shown to be mediated by superoxide [Gurjar et al., 2001]. Interestingly, Beck et al. [1998] and Kuo et al. [2000] reported independently that addition of superoxide to rat mesangial cells or to hepatocyte cultures, respectively, enhanced IL-1-induced iNOS expression, which, although not showing that superoxide mediates this IL-1-induced response, is in agreement with our results presented here.
On the other hand, peroxynitrite, which results from the reaction of superoxide with $\mathrm{NO}$, is another ROS that has been recently recognized as an important mediator of some IL-1-induced responses in various cells. In bovine articular chondrocytes, it was reported to mediate IL-1induced inhibition of proteoglycan synthesis [Oh et al., 1998]. However, it is unlikely that the inhibition of $\mathrm{NF}-\kappa \mathrm{B}$ activation and iNOS expression that occurred in SOD-treated cells, as shown in Figures 2 and 4, resulted from the unavailability of peroxynitrite. In fact, we have previously observed that NO exerts an inhibitory effect on NF- $\mathrm{kB}$ activation and iNOS expression [Mendes et al., 2002b], which argues against a role for peroxynitrite in those IL-1induced responses. Furthermore, we also observed that upon IL-1-treatment, the constitutive isoform of NOS (or NOS I) is rapidly degraded, whereas the inducible isoform takes a longer time to be expressed [Mendes et al., $2002 \mathrm{~b}]$. Therefore, the amount of NO produced by chondrocytes immediately after IL-1 treatment is probably very low, thus making the production of significant amounts of peroxynitrite improbable. Taken together, these results suggest that peroxynitrite is not the ROS required for IL-1 induction of NF- $\mathrm{KB}$ activation and iNOS expression in bovine articular chondrocytes.

In conclusion, the results presented here confirm our previous observations that ROS are required for IL-1-induced NF- $\mathrm{NB}$ activation and iNOS expression [Mendes et al., 2001]. More significantly, the present study identifies the superoxide radical as the ROS involved in mediating the IL-1-induced signaling pathway that leads to $\mathrm{NF}-\kappa \mathrm{B}$ activation and to the expression of $\mathrm{NF}-\kappa \mathrm{B}$-dependent genes in bovine articular chondrocytes.

\section{REFERENCES}

Allen RG, Tresini M. 2000. Oxidative stress and gene regulation. Free Radic Biol Med 28:463-499.

Bass DA, Parce JW, Dechatelet LR, Szejda P, Seeds MC, Thomas M. 1983. Flow cytometric studies of oxidative product formation by neutrophils: A graded response to membrane stimulation. J Immunol 130:1910-1917.

Beck KF, Eberhardt W, Walpen S, Apel M, Pfeilschifter J. 1998. Potentiation of nitric oxide synthase expression by superoxide in interleukin-1 $\beta$-stimulated rat mesangial cells. FEBS Lett 435:35-38.

Beg AA, Finco TS, Nantermet PV, Baldwin AS Jr. 1993. Tumor necrosis factor and interleukin-1 lead to phos-

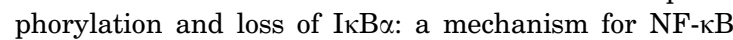
activiation. Mol Cell Biol 13:3301-3310. 
Blanco FJ, Lotz M. 1995. IL-1-induced nitric oxide inhibits chondrocyte proliferation via PGE2. Exp Cell Res 218: 319-325.

Cruz TF, Mills G, Pritzker KPH, Kandel RA. 1990. Inverse correlation between tyrosine phosphorylation and collagenase poduction in chondrocytes. Biochem J 269:717721.

Eberhardt W, Plüss C, Hummel R, Pfeilschifter J. 1998. Molecular mechanisms of inducible nitric oxide synthase gene expression by IL-1 $\beta$ and cAMP in rat mesangial cells. J Immunol 160:4961-4969.

Eberhardt W, Huwiler A, Beck KF, Walpen S, Pfeilschifter J. 2000. Amplification of IL-1 $\beta$-induced matrix metalloproteinase-9 expression by superoxide in rat glomerular mesangial cells is mediated by increased activities of NF$\kappa \mathrm{B}$ and activating protein- 1 and involves activation of the mitogen-activated protein kinase pathways. J Immunol 165:5788-5797.

Eberhardt W, Beck KF, Pfeilschifter J. 2002. Cytokineinduced expression of tPA is differentially modulated by NO and ROS in rat mesangial cells. Kidney Int 61:20-30.

Flescher E, Tripoli H, Salnikow K, Burns FJ. 1998. Oxidative stress suppresses transcription factor activities in stimulated lymphocytes. Clin Exp Immunol 112:242-247.

Green LC, Wagner DA, Glogowski J, Skipper PL, Wishnok JS, Tannenbaum SR. 1982. Analysis of nitrate, nitrite and $\left({ }^{15} \mathrm{~N}\right)$ nitrate in biological fluids. Anal Biochem 126 : 131-138.

Gurjar MV, Deleon J, Sharma RV, Bhalla RC. 2001. Role of reactive oxygen species in IL-1 $\beta$-stimulated sustained ERK activation and MMP-9 induction. Am J Physiol Heart Circ Physiol 281:H2568-2574.

Iademarco MF, McQuillan JJ, Rosen GD, Dean DC. 1992. Characterization of the promoter for vascular cell adhesion molecule-1 (VCAM-1). J Biol Chem 267: 16323-16329

Jin DY, Chae HZ, Rhee SG, Jeang KT. 1997. Regulatory role for a novel human thioredoxin peroxidase in NF- $\mathrm{kB}$ activation. J Biol Chem 272:30952-30961.

Kaszubska W, van Huijsduijnen RH, Ghersa P, DeRaemySchenk AM. 1993. Cyclic AMP-independent ATF family members interact with $\mathrm{NF}-\mathrm{\kappa B}$ and function in the activation of the E-selectin promoter in response to cytokines. Mol Cell Biol 13:7180-7190.

Kuo PC, Abe K, Schroeder RA. 2000. Superoxide enhances interleukin-1 $\beta$-mediated transcription of the hepatocyteinducible nitric oxide synthase gene. Gastroenterology 118:608-618.

Lakshminarayanan V, Drab-Weiss EA, Roebuck KA. 1998. $\mathrm{H}_{2} \mathrm{O}_{2}$ and tumor necrosis factor- $\alpha$ induce differential binding of the redox-responsive transcription factors AP1 and NF- $\mathrm{KB}$ to the interleukin-8 promoter in endothelial and epithelial cells. J Biol Chem 273:32670-32678.

LeBel CP, Ali SF, McKee M, Bondy SC. 1990. Organometalinduced increases in reactive oxygen species: The potential of $2^{\prime}, 7^{\prime}$-dichlorofluorecein diacetate as an index of neurotoxic damage. Toxicol Appl Pharmacol 104:17-24.

Lo YYC, Wong JMS, Cruz TF. 1996. Reactive oxygen species mediate cytokine activation of c-Jun $\mathrm{NH}_{2}$-terminal kinases. J Biol Chem 271:15703-15707.

Lo YYC, Conquer JA, Grinstein S, Cruz TF. 1998. Interleukin- $1 \beta$ induction of $\mathrm{c}$-fos and collagenase expression in articular chondrocytes: Involvement of reactive oxygen species. J Cell Biochem 69:19-29.

Lukiw WJ, Bazan NG. 1998. Strong nuclear factor-кB-DNA binding parallels cyclooxygenase-2 gene transcription in aging and in sporadic Alzheimer's disease superior temporal lobe neocortex. J Neurosci Res 53:583-592.

Manna SK, Zhang HJ, Yan T, Oberley LW, Aggarwal BB. 1998. Overexpression of manganese superoxide dismutase suppresses tumor necrosis factor-induced apoptosis and activation of nuclear transcription factor- $\mathrm{\kappa B}$ and activated protein-1. J Biol Chem 273:13245-13254.

Mendes AF, Carvalho AP, Caramona MM, Lopes MC. 2001. Diphenyleneiodonium inhibits $\mathrm{NF}-\mathrm{\kappa B}$ activation and iNOS expression induced by IL-1 $\beta$ : Involvement of reactive oxygen species. Med Inflamm 10:209-215.

Mendes AF, Caramona MM, Carvalho AP, Lopes MC. 2002a. Role of mitogen-activated protein kinases and tyrosine kinases on IL-1-induced NF- $\mathrm{KB}$ activation and iNOS expression in bovine articular chondrocytes. Nitric Oxide 6:35-44

Mendes AF, Carvalho AP, Caramona MM, Lopes MC. 2002b. Role of nitric oxide on the activation of NF- $\mathrm{kB}$, AP-1 and NOS II expression in articular chondrocytes. Inflamm Res 51:369-375.

Mendes AF, Caramona MM, Carvalho AP, Lopes MC. 2002c. Diacerhein and Rhein prevent interleukin-1 $\beta$ induced Nuclear Factor- $\kappa \mathrm{B}$ activation by inhibiting the degradation of Inhibitor $\kappa \mathrm{B}-\alpha$. Pharmacol Toxicol 91: $22-28$.

Meyer M, Schreck R, Baeuerle PA. 1993. $\mathrm{H}_{2} \mathrm{O}_{2}$ and antioxidants have opposite effects on activation of NF-kB and AP-1 in intact cells: AP-1 as secondary antioxidantresponsive factor. EMBO J 12:2005-2015.

Oh M, Fukuda K, Asada S, Yasuda Y, Tanaka S. 1998. Concurrent generation of nitric oxide and superoxide inhibits proteoglycan synthesis in bovine articular chondrocytes: Involvement of peroxynitrite. J Rheumatol 25:2169-2174.

Pelletier JP, DiBattista JA, Roughley P, McCollum R, Martel-Pelletier J. 1993. Cytokines and inflammation in cartilage degradation. Rheum Dis Clin North Am 19: 545-568.

Rathakrishnan C, Tiku K, Raghaven A, Tiku ML. 1992. Release of oxygen radicals by articular chondrocytes: A study of luminol-dependent chemiluminescence and hydrogen peroxide secretion. J Bone Miner Res 7:11391148 .

Schmidt KN, Amstad P, Cerutti P, Baeuerle PA. 1995. The roles of hydrogen peroxide and superoxide as messengers in the activation of transcription factor NF- $\mathrm{kB}$. Chem Biol 2:13-22.

Schoonbroodt S, Piette J. 2000. Oxidative stress interference with the nuclear factor- $\kappa \mathrm{B}$ activation pathways. Biochem Pharmacol 60:1075-1083.

Schreck R, Meier B, Männel DN, Dröge W, Baeuerle PA. 1992. Dithiocarbamates as potent inhibitors of Nuclear Factor $\kappa B$ activation in intact cells. J Exp Med 175:11811194.

Sen CK. 1998. Redox signaling and the emerging therapeutic potential of thiol antioxidants. Biochem Pharmacol 55:1747-1758.

Siebenlist U, Franzoso G, Brown K. 1994. Structure, regulation and function of NF-kB. Annu Rev Cell Biol 10:405-455. 
Suzuki YJ, Mizuno M, Packer L. 1995. Transient overexpression of catalase does not inhibit TNF- or PMA-induced NF- $\mathrm{BB}$ activation. Biochem Biophys Res Commun 210:537-541.

Tawara T, Shingu M, Nobunaga M, Naono T. 1991. Effects of recombinant human IL-1 $\beta$ on production of prostaglandin E2, leukotriene B4, NAG and superoxide by human synovial cells and chondrocytes. Inflammation 15:145-157.

Tiku ML, Yan YP, Chen KY. 1998. Hydroxyl radical formation in chondrocytes and cartilage as detected by electron paramagnetic resonance spectroscopy using spin trapping reagents. Free Radic Res 29:177-187.

Tiku ML, Gupta S, Deshmukh DR. 1999. Aggrecan degradation in chondrocytes is mediated by reactive oxygen species and protected by antioxidants. Free Radic Res 30:395-405.

Tiku ML, Shah R, Allison GT. 2000. Evidence linking chondrocyte lipid peroxidation to cartilage protein degradation. Possible role in cartilage aging and the pathogenesis of osteoarthritis. J Biol Chem 275:20069-20076.
Wesselborg S, Bauer MKA, Vogt M, Schmitz ML, SchulzeOsthoff K. 1997. Activation of transcription factor NF-kB and p38 mitogen-activated protein kinase is mediated by distinct and separate stress effector pathways. J Biol Chem 272:12422-12429.

Weyand CM. 2000. New insights into the pathogenesis of rheumatoid arthritis. Rheumatology 39(Suppl 1): $3-8$.

Woods JS, Ellis ME, Dieguez-Acuña FJ, Corral J. 1999. Activation of NF- $\mathrm{KB}$ in normal kidney epithelial (NRK52E) cells is mediated via a redox-insensitive, calcium-dependent pathway. Toxicol Appl Pharmacol 154:219-227.

Xie Q, Kashiwabara Y, Nathan C. 1994. Role of transcription factor $\mathrm{NF}-\mathrm{\kappa B} / \mathrm{Rel}$ in induction of nitric oxide synthase. J Biol Chem 269:4705-4708.

Yoshida S, Kato T, Sakurada S, Kurono C, Yang J-P, Matsui N, Soji T, Okamoto T. 1999. Inhibition of IL-6 and IL-8 induction from cultured rheumatoid and synovial fibroblasts by treatment with aurothioglucose. Int Immunol 11:151-158. 